OPEN ACCESS

Edited by:

Jixin Zhong,

Case Western Reserve University,

United States

Reviewed by:

Hui Liu,

University of California, San

Francisco, United States

Yanlin He,

Baylor College of Medicine, United States

*Correspondence:

Edessa Negera

edessan@yahoo.com

Specialty section:

This article was submitted to

Inflammation,

a section of the journal

Frontiers in Immunology

Received: 13 July 2017

Accepted: 31 August 2017

Published: 15 September 2017

Citation:

Negera E, Bobosha K, Walker SL,

Endale B, Howe R, Aseffa A,

Dockrell HM and Lockwood DN

(2017) New Insight into

the Pathogenesis of Erythema

Nodosum Leprosum: The Role

of Activated Memory T-Cells.

Front. Immunol. 8:1149.

doi: 10.3389/fimmu.2017.01149

\section{New Insight into the Pathogenesis of Erythema Nodosum Leprosum: The Role of Activated Memory T-Cells}

\author{
Edessa Negera ${ }^{1,2 *}$, Kidist Bobosha ${ }^{2}$, Stephen L. Walker ${ }^{1}$, Birtukan Endale ${ }^{2}$, \\ Rawleigh Howe' ${ }^{2}$, Abraham Aseffa ${ }^{2}$, Hazel M. Dockrell' ${ }^{1}$ and Diana N. Lockwood ${ }^{1}$ \\ ${ }^{1}$ London School of Hygiene and Tropical Medicine, Faculty of Infectious Diseases, London, United Kingdom, ${ }^{2}$ Armauer \\ Hansen Research Institute, Addis Ababa, Ethiopia
}

Memory T-cells, particularly, effector memory T cells are implicated in the pathogenesis of inflammatory diseases and may contribute to tissue injury and disease progression. Although erythema nodosum leprosum (ENL) is an inflammatory complication of leprosy, the role of memory $T$ cell subsets has never been studied in this patient group. The aim of this study was at investigate the kinetics of memory $T$ cell subsets in patients with ENL before and after prednisolone treatment. A case-control study design was used to recruit 35 untreated patients with ENL and 25 non-reactional lepromatous leprosy (LL) patient controls at ALERT Hospital, Ethiopia. Venous blood samples were obtained before, during, and after treatment from each patient. Peripheral blood mononuclear cells (PBMCs) were isolated and used for immunophenotyping of $T$ cell activation and memory T-cell subsets by flow cytometry. The kinetics of these immune cells in patients with ENL before and after treatment were compared with LL patient controls as well as within ENL cases at different time points. The median percentage of $\mathrm{CD}^{+}, \mathrm{CD}^{+}$, and $\mathrm{CD}^{+}{ }^{+}$-cells expressing activated T-cells were significantly higher in the PBMCs from patients with ENL than from LL patient controls before treatment. The median percentage of central and activated memory T-cells was significantly increased in patients with ENL compared to LL patient controls before treatment. Interestingly, patients with ENL had a lower percentage of naïve T cells $(27.7 \%)$ compared to LL patient controls $(59.5 \%)(P<0.0001)$ before treatment. However, after prednisolone treatment, patients with ENL had a higher median percentage of naïve T-cells (43.0\%) than LL controls (33.0\%) $(P<0.001)$. The median percentage of activated T-cells (effector memory and effector T-cells) was significantly increased in patients with ENL (59.2\%) before treatment compared to after treatment with prednisolone (33.9\%) $(P<0.005)$. This is the first work which has shown T-cell activation and the different subsets of memory $T$ cells in untreated patients with ENL. Consequently, this study delineates the role of T-cell activation in the pathogenesis of ENL reaction and challenges the long-standing dogma of immune complex as a sole etiology of ENL reaction.

Keywords: erythema nodosum leprosum, ethiopia, leprosy, memory T-cells, prednisolone, reaction 


\section{INTRODUCTION}

Leprosy is a disease caused by Mycobacterium leprae, an intracellular acid-fast bacillus. It mainly infects the skin and peripheral nerves. Leprosy is a disease with a five-district forms called spectrum with the localized tuberculoid leprosy (TT) and the generalized lepromatous leprosy (LL) forming the two poles of the spectrum (1).

Leprosy reactions [reversal reactions and erythema nodosum leprosum (ENL)] are immune-mediated inflammatory complications of the disease which can occur before, during, or after successful completion of multidrug treatment (2). They cause a significant morbidity and nerve damage in leprosy patients (3). ENL is an inflammatory complication of leprosy, manifesting as tender erythematous skin lesions and systemic features of disease including fever, neuritis, and bone pain (4).

Immunological memory is a characteristic of adaptive immunity. After infection, some antigen experienced T-cells generate memory T-cells which can provide life-long protection against the same infection. These memory $\mathrm{T}$ cells rapidly undergo clonal expansion to fight off the reoccurrence of the same infection (5). Memory is a signature of the acquired immune system. It results from antigen-specific lymphocytes clonal expansion and differentiation, which eventually persist for a lifetime (6). Memory lymphocytes ensure immediate protection in peripheral tissues and provide recall responses to antigens in secondary lymphoid organs. In the cellular immune system, these functions are carried out by distinct cell types called effector and central memory T-cells ( $\mathrm{T}_{\mathrm{CM}}$ cells). Protective memory is mediated by effector memory T-cells ( $\mathrm{T}_{\mathrm{EM}}$ cells) that roam to inflamed peripheral tissues and confer immediate effector function, whereas reactive memory is carried out by $\mathrm{T}_{\mathrm{CM}}$ cells that home to T-cell areas of secondary lymphoid organs (7). $\mathrm{T}_{\mathrm{CM}}$ cells proliferate and differentiate to effector cells in response to antigenic stimulation (5).

Memory T-cells are characterized into two groups based on their phenotypic and functional profiles as $\mathrm{T}_{\mathrm{CM}}$ and $\mathrm{T}_{\mathrm{EM}}$ cells (7). The presence or absence of lymph node homing receptors CD62L (L-selectin) and C-C chemokine receptpr-7 (CCR7) on the cell surface are used to distinguish between $\mathrm{T}_{\mathrm{CM}}$ and $\mathrm{T}_{\mathrm{EM}}$ cells (8). CD62L or L-selection is a glycoprotein adhesion molecule which serves as a homing receptor for lymphocytes to enter secondary lymphoid tissues through high endothelial venules. CD62L shed from the surface during T-cell activation resulting in CD62L-negative effector cells (effector cells and $\mathrm{T}_{\mathrm{EM}}$ cells). Hence, effector memory T-lymphocytes do not express L-selectin, as they circulate in the periphery and have immediate effector functions upon encountering antigen. Unlike $\mathrm{T}_{\mathrm{EM}}$ cells, CD62L and CCR7 are present on the surface of $\mathrm{T}_{\mathrm{CM}}(7)$. Naïve ( $\mathrm{N}_{\mathrm{TC}}$ ) and $\mathrm{T}_{\mathrm{CM}}$ cells express CD62L and CCR7 for migration to secondary lymphoid organ. In the absence of CD62L and CCR7 molecules, $\mathrm{T}_{\mathrm{EM}}$ and effector $\mathrm{T}$ cells $\left(\mathrm{T}_{\mathrm{EC}}\right)$ build up in the peripheral tissues. $\mathrm{T}_{\mathrm{EC}}$ cells are terminally differentiated memory T-cells. They are the relatively short-lived activated cells whose functions involve the interaction of an armed $\mathrm{T}_{\mathrm{EC}}$ cell with a target cell displaying specific antigen. They neither display memory marker (CD45RO) nor the homing receptor (CD62L) $(7,8)$.
Central memory T-cells produce IL-2, whereas $\mathrm{T}_{\mathrm{EM}}$ cells are characterized by increased secretion of effector cytokines such as IFN- $\gamma$ and IL-4 (7). $\mathrm{T}_{\mathrm{CM}}$ cells are moderately long-lived memory cells, capable of differentiating into shorter-lived $\mathrm{T}_{\mathrm{EM}}$ cells upon antigen stimulation. In turn, $\mathrm{T}_{\mathrm{EM}}$ cells differentiate into $\mathrm{T}_{\mathrm{EC}}$ cells. $\mathrm{T}_{\mathrm{EC}}$ cells represent terminally differentiated $\mathrm{T}_{\mathrm{EM}}$ cells. Apoptotic death is the outcome of $T_{E C}$ cells upon increased proliferation and antigen exposure $(9,10)$. A $\mathrm{N}_{\mathrm{TC}}$ is a mature differentiated T-cell that has not encountered its cognate antigen within the periphery. $\mathrm{N}_{\mathrm{TC}} \mathrm{S}$ are usually characterized by the surface expression of L-selectin (CD62L). They do not express memory markers (CD45RO) or activation markers such as CD25, CD44, and CD69. $\mathrm{N}_{\mathrm{TC}}$ do not proliferate until they encounter their corresponding antigens. Stem memory T-cells have recently been described as sets of memory T-cells in mice and humans comprise $2-4 \%$ of $\mathrm{CD}^{+}$and $\mathrm{CD}^{+}{ }^{+} \mathrm{T}$-cells population in the periphery. It is speculated that these cells represent the earliest and long-lasting developmental stage of memory T-cells, displaying stem cell-like properties and expressing a gene profile between naïve and $\mathrm{T}_{\mathrm{CM}}$ cells (10).

Few studies have intended to identify the memory $\mathrm{T}$ cell subsets in leprosy. One earlier study has shown that in fresh and unstimulated blood leukocytes from leprosy patients, memory $\mathrm{T}$ cells predominated in the PB form of the disease and correlated with IFN- $\gamma$ production but such result was not observed in MB patients (11). However, the study did not use an experimental design that allowed classification of memory $\mathrm{T}$ cell into subsets.

The correlation between $\mathrm{T}_{\mathrm{CM}}$ cell expression and proinflammatory cytokine production with clinical presentation of multibacillary leprosy relapse case has been investigated (12). Increased frequency of $\mathrm{T}_{\mathrm{CM}}$ cells in relapsed patients was strongly correlated with the bacillary index and the number of skin lesions was reported by these authors. The study did not give attention to the memory subsets in leprosy spectrum rather they focused on relapse cases. Recently, a cross-sectional study of memory T-cells among type-1 reactions (T1R) has shown that circulating $\mathrm{CD} 4^{+}$ $\mathrm{T}_{\mathrm{EM}}, \mathrm{CD} 8^{+} \mathrm{T}_{\mathrm{Ec}}$, and pro-inflammatory cytokines increased at the onset of T1R in BL patients (13).

Memory T-cells have not been well characterized across leprosy spectrum as well as in leprosy reactions particularly in ENL reactions. In the present study, for the first time we described memory-T cell subsets in LL and ENL reactions before and after prednisolone treatment.

\section{MATERIALS AND METHODS}

\section{Study Design}

A case-control study with follow-up for 28 weeks was used to recruit 35 patients with ENL reaction and 25 non-reactional LL patient controls between December 2014 and January 2016 at ALERT Hospital, Ethiopia.

\section{Clinical Case Definitions}

The clinical assessment of the patient was used as main diagnostic criteria for ENL cases LL patient controls (4). 


\section{Erythema Nodosum Leprosum}

Erythema nodosum leprosum was clinically diagnosed when a patient had painful tender subcutaneous erythematous skin lesions with or without systemic features such as fever, neuritis, and bone pain occurring in patients with LL or borderline LL.

\section{Lepromatous Leprosy}

Lepromatous leprosy was clinically diagnosed when a patient had widely disseminated nodular lesions with ill-defined borders and BI above 2.

\section{Acute ENL}

Acute ENL was defined as an ENL episode lasting less than 24 weeks of prednisolone treatment.

\section{Chronic ENL}

Chronic ENL was defined as an ENL occurring for 24 weeks or more during which a patient has required ENL treatment either continuously or where any treatment free period has been 27 days or less.

\section{Recurrent ENL}

Recurrent ENL was defined as a second or subsequent episode of ENL occurring 28 days or more after stopping or steady decrease of steroid treatment for ENL.

\section{ENL Recurrence or Flare-up}

Erythema nodosum leprosum recurrence or flare-up was defined as the appearance of new ENL nodules after initial control, either while on treatment or after 28 days off treatment.

\section{New ENL Case}

New ENL case was defined as the occurrence of ENL for the first time in a patient with LL.

\section{Demographic and Clinical Data Collection}

Structured questionnaire were used for clinical data recording for each participant. The ENL International STudy (ENLIST) format was modified and used for clinical data recording. The data collection sheet included the demographic, clinical, and diagnostic information set following the standard guideline at each time point. The clinical information included core points such as the clinical feature, skin lesion, nerve functions, and systemic involvement.

\section{Clinical Sample Collection}

Blood samples were obtained from each patient three times: at recruitment before prednisolone administration and after 12 and 24 weeks of prednisolone treatment foe ENL cases. The 12th week was chosen since the steady decrease in prednisolone after 12th week reaches less than half of the start dose and after 24th-week prednisolone administration normally off unless the patient experiences a chronic condition. The third time-point sample (24th week) was obtained when an ENL patient completed prednisolone treatment and the free treatment period is 15 days or more.

\section{Peripheral Blood Mononuclear Cell (PBMC) Isolation, Freezing, and Thawing}

Ten milliliters of venous blood was collected in sterile BD heparinized vacutainer ${ }^{\circledR}$ tubes (BD, Franklin, Lakes, NJ, USA). PBMCs were separated by density gradient centrifugation at $800 \times g$ for 25 min on Ficoll-Hypaque (Histopaque, Sigma Aldrich, UK) as described earlier (14). Cells were washed three times in sterile phosphate-buffered saline solution (1× PBS, Sigma Aldrich ${ }^{\circledast}$, UK) and resuspended with $1 \mathrm{ml}$ of Roswell Park Memorial Institute [RPMI medium $1640(1 \times)+$ GlutaMAX $^{\mathrm{TM}}+$ Pen-Strip $\left(\mathrm{GIBCO}^{\mathrm{TM}}\right.$, Life technologies ${ }^{\mathrm{TM}}$, UK)]. Cell viability was determined by $0.4 \%$ sterile Trypan Blue solution (Sigma Aldrich ${ }^{\circledR}, \mathrm{UK}$ ) ranged from 94 to $98 \%$. PBMC freezing was performed using a freezing medium composed of $20 \%$ fetal bovine serum (FBS, heat inactivated, endotoxin tested $\leq 5 \mathrm{EU} / \mathrm{ml}$, GIBCO ${ }^{\circledast}$ Life technologies, UK), 20\% dimethyl sulfoxide in RPMI medium $1640(1 \times)$. Cells were kept at $80^{\circ} \mathrm{C}$ for $48-72 \mathrm{~h}$ and transferred to liquid nitrogen. Thomson et al. method was used for cell thawing (15). The procedure is briefly described as: cells were removed from liquid nitrogen and taken to a water bath (preadjusted to $37^{\circ} \mathrm{C}$ ) for $30 \mathrm{~s}$ until thawed half way and resuspended in 10\% FBS in RPMI medium $1640(1 \times)$ at $37^{\circ} \mathrm{C}$ containing $1 / 10,000$ benzonase until completely thawed, washed two times (5 min each) and counted with trypan blue. A percentage viability of above $90 \%$ was obtained. Cell concentration was adjusted to $10^{6}$ cells $/ \mathrm{ml}$ in RPMI. Then, $1 \mathrm{ml} /$ well cell suspension was pipetted on 24-well polystyrene cell culture plate (Corning ${ }^{\circledR}$ Costar $^{\circledR}$ cell culture plates) and incubated at $37^{\circ} \mathrm{C}$ in a $5 \%$ carbon dioxide incubator. After an overnight resting, cells were brought to flow cytometry staining room for staining with fluorochromes conjugated antibodies as described below.

\section{Surface Staining for Flow Cytometry}

About $1 \times 10^{6} / \mathrm{ml}$ cells' suspension was transferred to roundbottomed FACS tubes (Falcon ${ }^{\circledR}$, BD, UK) followed by washing twice at $400 \times \mathrm{g}$ for $5 \mathrm{~min}$ at RT. Then, cells were resuspended in $50 \mu \mathrm{l}$ of PBS and incubated in $1 \mathrm{ml}$ of $10 \%$ human AB serum (Sigma Aldrich ${ }^{\circledast}, \mathrm{UK}$ ) for $10 \mathrm{~min}$ in the dark at room temperature to block non-specific Fc-mediated interactions and followed by centrifugation at $400 \times g$ for $5 \mathrm{~min}$. After resuspending cells in $50 \mu \mathrm{l}$ PBS buffer, live/dead staining was performed at a concentration of $1 \mu \mathrm{l} / 1 \mathrm{ml}$ live/dead stain (V500 Aqua, Invitrogen, Life technologies, UK) for $15 \mathrm{~min}$ at $4^{\circ} \mathrm{C}$ in the dark. Cells were washed once and stained for surface markers directed against anti-human CD3 (APC 450), anti-human CD4 (eFluoro780), anti-human CD8 (PerCp-Cy5.5), anti-human CD62L (APC), and anti-human CD45RO (PE), all from BD, Biosciences, UK. We used for each maker FMO, compensation controls, and unstained cells. Unstained cells were used to exclude the autofluorescence of cells. Cell viability was also checked before staining using $0.4 \%$ trypan blue.

\section{Sample Acquisition and Gating Strategy}

After the voltages on the photomultiplier tubes and compensation controls setting, the worksheet area was switched from the normal worksheet to the global worksheet. For inspection 
purpose, the plots were produced on worksheet such as FSC-H versus FSC-A (to inspect the singlets), FSC-A versus viability marker (to inspect viable cells), and SSC-A versus FSC-A (to inspect populations such as lymphocytes, monocytes, granulocytes, etc.). The threshold for FSC was set to 5,000. For each sample, 500,000-1,000,000 cells were acquired.

Cells were gated into subpopulations with Flow Jo version 10 (Tree Star, USA) by logicle (bi-exponential) method as recommended by Mohan et al. (16) and Ehlers (17). Activated and memory T-cells were defined as $\mathrm{CD}^{+} \mathrm{CD}^{+} 2 \mathrm{~L}^{-}$and $\mathrm{CD}^{+} \mathrm{CD}^{2} 5 \mathrm{RO}^{+}$, respectively. Memory $\mathrm{T}$-cells were further grouped into $\mathrm{T}_{\mathrm{CM}}$ cells $\left(\mathrm{CD} 3{ }^{+} \mathrm{CD} 45 \mathrm{RO}^{+} \mathrm{CD} 62 \mathrm{~L}^{+}\right)$and activated memory T-cells $\left(\mathrm{CD}^{+}{ }^{+} \mathrm{CD} 45 \mathrm{RO}^{+} \mathrm{CD}^{-} 2 \mathrm{~L}^{-}\right) . \mathrm{T}_{\mathrm{EC}}$ and $\mathrm{N}_{\mathrm{TC}}$ sere

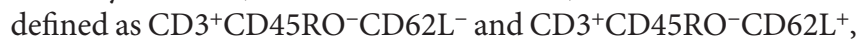
respectively (Figure 1). The relative percentage of each subpopulation was copied to excel for each sample and finally an excel spreadsheet electronic data were generated and used for subsequent statistical analysis.

\section{Statistical Analysis}

Differences in percentage of T-cell subsets were computed and statistically tested with two-tailed Mann-Whitney $U$ test or Wilcoxon signed rank test for non-parametric distribution using STATA 14 ver. 2 (San Diego, CA, USA). Graphs were produced by GraphPad Prism version 5.01 for Windows (GraphPad Software, San Diego, CA, USA). Median and Hodges-Lehmann estimator were used for result presentation. Hodges-Lehmann is used to measure the effect size for non-parametric data (18). P-Value correction was applied for multiple comparisons. A statistical significance level of 0.05 was used to test the difference between cases and controls.

\section{RESULTS}

We described the median percentage of activated T-cells $\left(\mathrm{CD} 62 \mathrm{~L}^{-}\right)$, total memory T-cells $\left(\mathrm{CD} 45 \mathrm{RO}^{+}\right)$, and the subgroups of memory T-cells before, during, and after treatment of ENL patients and compared the results with non-reactional LL patient controls as well as within ENL patients.

\section{Increased T-Cell Activation in Untreated ENL Patients}

The percentage of activated $\mathrm{CD}^{+} \mathrm{T}$-cells $\left(\mathrm{CD}^{+} \mathrm{CD}^{+} \mathrm{L}^{-}\right)$was significantly increased in untreated ENL patients $(59.3 \%)$ in contrast to non-reactional LL patient controls $(37.7 \%)(P<0.0001$; $\Delta \mathrm{HL}=22.4 \%)$. However, after treatment statistically a significant difference was not obtained between the groups. Similarly, the median percentage of activated $\mathrm{CD} 4^{+} \mathrm{T}$-cells $\left(\mathrm{CD} 4^{+} \mathrm{CD} 62 \mathrm{~L}^{-}\right)$ was significantly higher (50.7\%) in PBMCs of patients with ENL than in LL patient controls $(27.1 \%)$ before treatment $(P<0.0001$; $\Delta \mathrm{HL}=19.1 \%)$. However, a significant difference was not observed during and after treatment $(P>0.05)$. Nearly two-third of CD8 ${ }^{+}$ T-cells $(71.2 \%)$ was activated $\left(\mathrm{CD}^{+} \mathrm{CD}^{-} \mathrm{L}^{-}\right)$in untreated ENL patients while it was only $45.4 \%$ in LL patient controls $(P<0.0001$; $\Delta \mathrm{HL}=27.9 \%)$. On the other hand, after treatment, the frequency of activated CD8 ${ }^{+}$T-cells was significantly decreased to $34.5 \%$ in patients with ENL compared to $45.2 \%$ in LL patient controls $(P \leq 0.05 ; \Delta \mathrm{HL}=10.1 \%)$ (Figure 2A).

When the trend of T-cell activation within ENL is compared before and after treatment, it was found that the median percentage of $\mathrm{CD}^{+}$-activated T-cells before starting prednisolone treatment was higher $(59.2 \%)$ than during treatment $(47.0 \%)$ $(P \leq 0.05)$. After treatment, the median percentage of activated $\mathrm{CD}^{+}$T-cells was decreased to $33.9 \%$, which was significantly lower than before treatment $(P<0.0001 ; \Delta \mathrm{HL}=25.5 \%)$. Likewise, the median percentage of $\mathrm{CD}^{+}$-activated T-cells was significantly higher $(50.7 \%)$ before treatment than during treatment $(29.7 \%)(P<0.0001 ; \Delta \mathrm{HL}=17.75 \%)$. Similarly, the median percentage of activated $\mathrm{CD}^{+}$T-cells was significantly higher (71.2\%) before treatment than during (59.5\%) and after $(34.5 \%)$ treatment $(P \leq 0.05)$ (Figure $2 \mathbf{B})$.
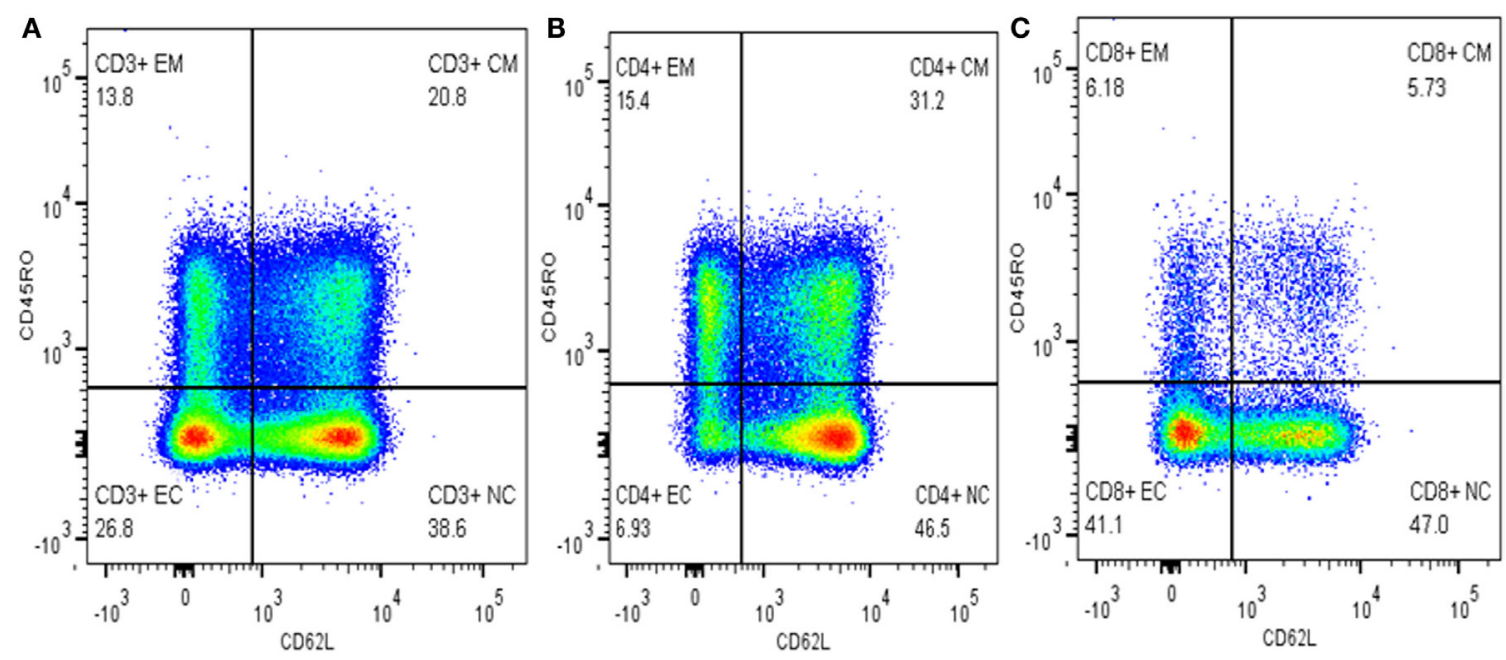

FIGURE 1 | Gating memory T-cells on different cell types. (A) Gated on CD3+ T-cells, (B) gated on CD4+ T-cells, and (C) gated on CD8+ T-cells. 

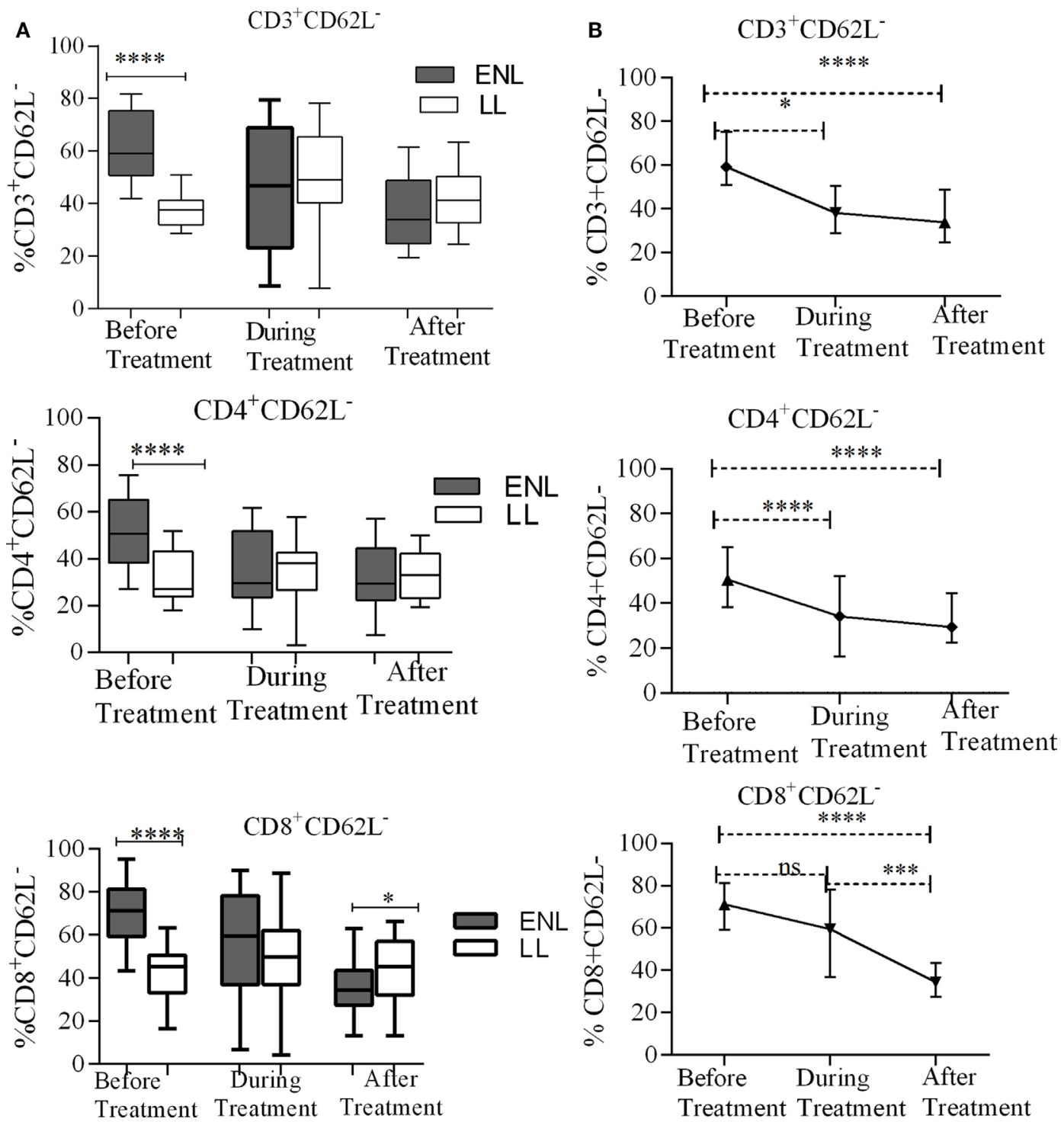

FIGURE 2 | Median percentage of total $\mathrm{CD}^{+}, \mathrm{CD}^{+}$, and $\mathrm{CD}^{+}$activated T-cells: (A) in patients with erythema nodosum leprosum (ENL) and lepromatous leprosy (LL) controls before, during, and after treatment, (B) within ENL patients before, during, and after treatment. ${ }^{\star} P \leq 0.05 ;{ }^{\star \star \star} P<0.001 ;{ }^{\star \star \star \star} P<0.0001$. Box and whiskers $(\mathbf{A})$ and error bars $(\mathbf{B})$ show median \pm interquartile range.

\section{Increased Total Memory T-Cells in Untreated ENL Patients}

Erythema nodosum leprosum patients had significantly increased $\mathrm{CD}^{+}$total memory T-cell $\left(\mathrm{CD}^{+} \mathrm{CD} 45 \mathrm{RO}^{+}\right)(40 \%)$ compared to LL patient' controls $(28 \%)$ before treatment $(P \leq 0.005$; $\Delta \mathrm{HL}=10.5 \%)$. After treatment, the median percentage of $\mathrm{CD}^{+}$ total memory T-cells in ENL patients and LL controls were 31.2 and $32.7 \%$, respectively, and the result was not statistically significantly different $(P>0.05)$. Similarly, the median percentage of $\mathrm{CD}^{+}$total memory T-cells $\left(\mathrm{CD} 4^{+} \mathrm{CD} 45 \mathrm{RO}^{+}\right)$was increased in untreated ENL patients (50\%) compared to LL patient controls $(30.5 \%)(P<0.0001 ; \Delta \mathrm{HL}=20.3 \%)$. After treatment, the median percentage of $\mathrm{CD}^{+}$total memory T-cells in ENL patients
(45.0\%) was not significantly different compared to LL patient controls $(41.8 \%)(P>0.05)$. Interestingly, the median percentage of $\mathrm{CD}^{+}$memory T-cells $\left(\mathrm{CD}^{+}{ }^{+} \mathrm{CD} 45 \mathrm{RO}^{+}\right)$was not statistically significantly different between the two groups before and after treatment (Figure 3A).

When the median percentage of total memory T-cells was compared within ENL patients before, during, and after treatment, it was found that the median percentage of $\mathrm{CD}^{+}$total memory T-cells was significantly higher $(41.1 \%)$ before treatment than during treatment $(29.2 \%)(P \leq 0.001 ; \Delta \mathrm{HL}=11.2 \%)$ and after treatment $(31.5 \%)(P \leq 0.001 ; \Delta \mathrm{HL}=9.8 \%)$. Similarly, the median percentage of $\mathrm{CD}^{+}$total memory T-cells was $52.3 \%$ before treatment and significantly decreased to $29.2 \%$ during treatment $(P<0.0001 ; \Delta \mathrm{HL}=22.1 \%)$. On the other hand, unlike 
A
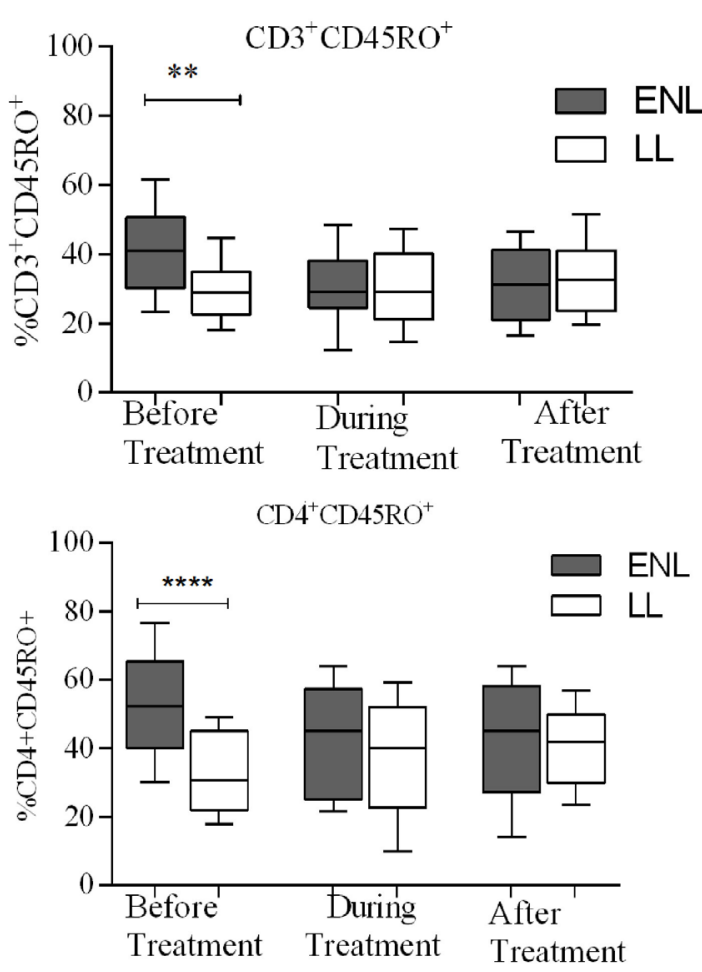

B

\section{$\mathrm{CD}^{+} \mathrm{CD} 45 \mathrm{RO}^{+}$}

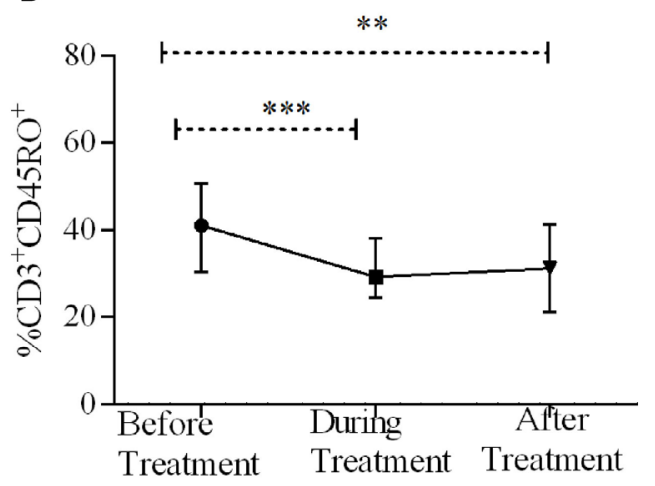

$\mathrm{CD}^{+} \mathrm{CD} 45 \mathrm{RO}^{+}$
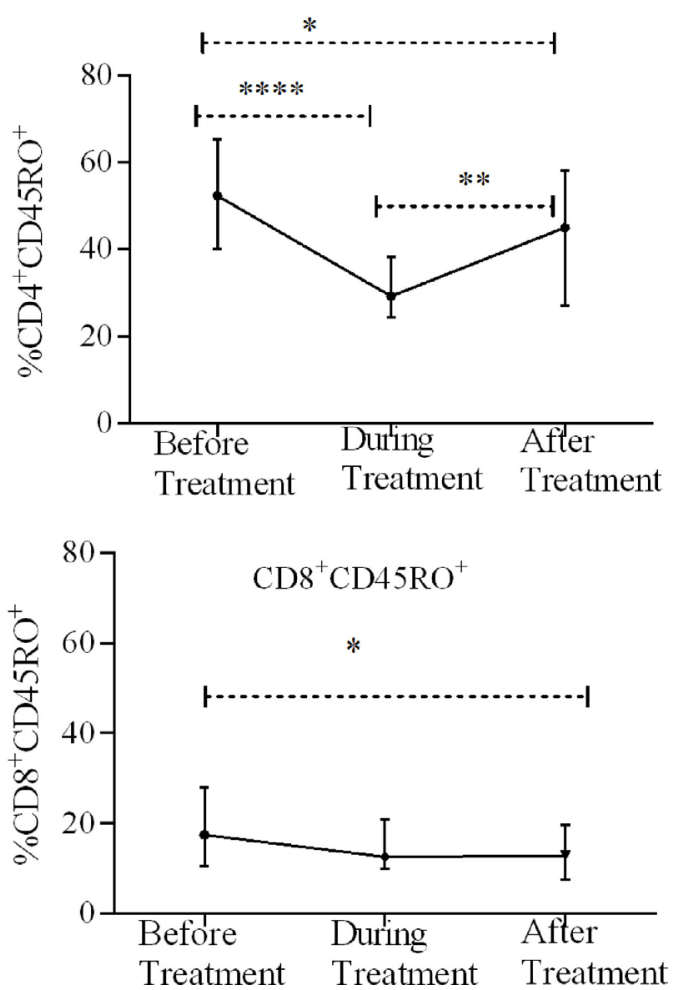

FIGURE 3 Median percentage of total $\mathrm{CD}^{+}, \mathrm{CD}^{+}$, and $\mathrm{CD} 8^{+}$memory T-cells: (A) in patients with erythema nodosum leprosum (ENL) and lepromatous leprosy (LL) controls before, during, and after treatment, (B) within ENL patients before, during, and after treatment. ${ }^{\star} P \leq 0.05$; ${ }^{\star \star} P<0.005$; ${ }^{* \star \star} P<0.001$; and ${ }^{\star \star \star \star} P<0.0001$. Box and whiskers $(\mathbf{A})$ and error bars $(\mathbf{B})$ show median \pm interquartile range.

$\mathrm{CD}^{+}$and $\mathrm{CD} 4^{+}$memory T-cells, the median percentage of $\mathrm{CD} 8^{+}$ memory T-cells did not change within ENL patients before, during, and after treatment (Figure 3B).

\section{Increased $\mathrm{T}_{\mathrm{EM}}$ Cells in Patients with ENL}

Effector memory T-cells are memory T-cells which have lost their CD62L expression while migrating to the tissue and progressively gain functionality with further differentiation to $\mathrm{T}_{\mathrm{EC}}$ cells also called terminally differentiated T-cells (19). Measurement of $\mathrm{T}_{\mathrm{EM}}$ cells is the most commonly used method to determine the extent of T-cell activation in a disease state. We measured the proportion of $\mathrm{T}_{\mathrm{EC}}$ cells in unstimulated PBMCs from patients with ENL and LL controls before, during, and after treatment to prove our hypothesis that ENL is associated with increased T-cell activation.

The median percentage of $\mathrm{CD}^{+} \mathrm{T}_{\mathrm{EM}}$ cells $\left(\mathrm{CD}^{+}{ }^{+} \mathrm{CD} 45 \mathrm{RO}^{+}\right.$ $\mathrm{CD}^{2} \mathrm{~L}^{-}$) in the PBMCs of patients with ENL was $26.6 \%$, which was significantly higher than in LL patient controls $(8.0 \%)$ before treatment $(P<0.0001 ; \Delta \mathrm{HL}=18.3 \%)$. Conversely, the percentage of $\mathrm{CD}^{+} \mathrm{T}_{\mathrm{EM}}$ cell was found to be lower in patients with ENL (7.6\%) than in LL patient controls (10.4\%) after treatment $(P \leq 0.05 ; \Delta \mathrm{HL}=3.5 \%)$. Similarly, the median percentage 
of $\mathrm{CD}^{+} \mathrm{T}_{\mathrm{EM}}$ cells $\left(\mathrm{CD} 4{ }^{+} \mathrm{CD} 45 \mathrm{RO}^{+} \mathrm{CD} 2 \mathrm{~L}^{-}\right)$in the PBMCs of patients with ENL was nearly three times (24.6\%) higher than in the PBMCs of LL patient controls (8.9\%) before treatment $(P<0.0001 ; \Delta \mathrm{HL}=18.4 \%)$. However, unlike $\mathrm{CD}^{+} \mathrm{T}_{\mathrm{EC}}$ cells, the median percentage of $\mathrm{CD} 4^{+} \mathrm{T}_{\mathrm{EC}}$ cells was not significantly different between the two groups after treatment $(P>0.05)$. Likewise the median percentage of $\mathrm{CD} 8^{+} \mathrm{T}_{\mathrm{EM}}$ cells $\left(\mathrm{CD} 8^{+} \mathrm{CD} 45 \mathrm{RO}^{+} \mathrm{CD} 62 \mathrm{~L}^{-}\right)$ was significantly higher in patients with ENL (16.5\%) than in LL patient controls $(7.2 \%)$ before treatment $(P<0.001$; $\Delta \mathrm{HL}=6.7 \%)$. However, after treatment, the median percentage of $\mathrm{CD}^{+} \mathrm{T}_{\mathrm{EM}}$ cells in patients with ENL and LL controls did not show significant difference (Figure 4A).

Trend analysis has shown that $\mathrm{T}_{\mathrm{EM}}$ cells significantly decreased in ENL patients after prednisolone treatment.
Untreated patients with ENL reactions had a higher $\mathrm{CD}^{+}$ $\mathrm{T}_{\mathrm{EM}}$ cells $(26.6 \%)$ than during treatment $(16.8 \%)(P<0.0001$; $\Delta \mathrm{HL}=11.88 \%)$. The percentage of $\mathrm{CD}^{+} \mathrm{T}$-cells expressing $\mathrm{T}_{\mathrm{EM}}$ cells $\left(\mathrm{CD}^{+} \mathrm{CD} 45 \mathrm{RO}^{+} \mathrm{CD} 2 \mathrm{~L}^{-}\right)$was considerably decreased to $7.6 \%$ after treatment, which was substantially lower than the median percentage of $\mathrm{CD}^{+}{ }^{+} \mathrm{T}_{\mathrm{EM}}$ cells before treatment $(P<0.0001 ; \Delta \mathrm{HL}=20.0 \%)$. Likewise, the median percentage of $\mathrm{CD}^{+}{ }^{+} \mathrm{T}_{\mathrm{EM}}\left(\mathrm{CD} 4{ }^{+} \mathrm{CD} 45 \mathrm{RO}^{+} \mathrm{CD} 2 \mathrm{~L}^{-}\right)$cells was more than twofold higher $(24.6 \%)$ before treatment compared to during treatment $(11.4 \%)$ and the difference was statistically significant $(P<0.0001 ; \Delta \mathrm{HL}=15.54 \%)$. The percentage of $\mathrm{CD}^{+} \mathrm{T}_{\mathrm{EM}}$ cells was remarkably reduced to $9.6 \%$ after treatment indicating the decreasing tendency of $\mathrm{T}$-cell activation after prednisolone treatment of patients with ENL. About $16.5 \%$ of $\mathrm{CD}^{+}$T-cells
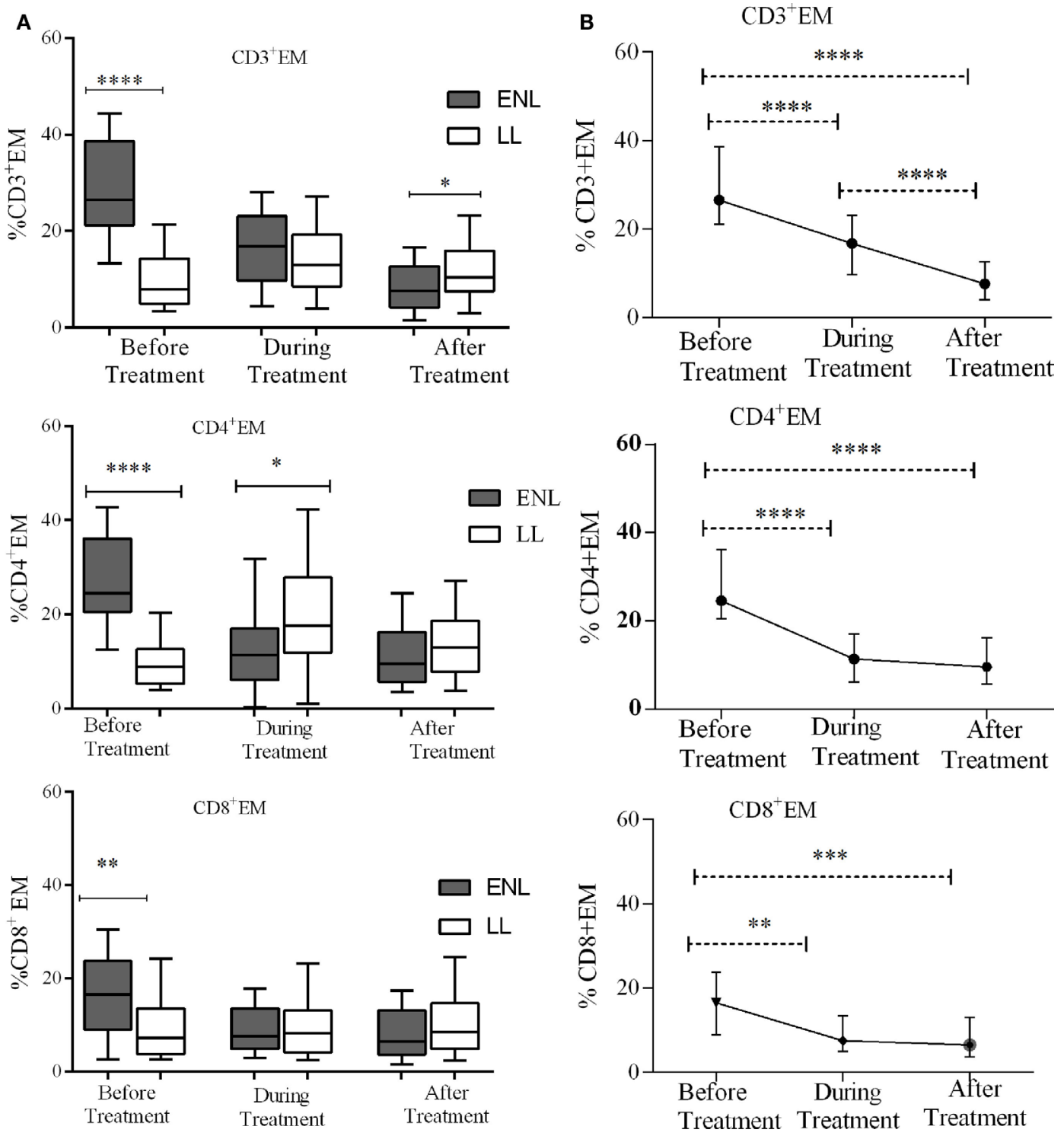

FIGURE 4 | Median percentage of $\mathrm{CD}^{+}, \mathrm{CD}^{+}$, and $\mathrm{CD}^{+}$effector memory T-cells: (A) in patients with erythema nodosum leprosum (ENL) and lepromatous leprosy (LL) controls before, during and after treatment, (B) within ENL patients before, during, and after treatment. ${ }^{\star} P \leq 0.05$; ${ }^{* \star} P<0.005$; ${ }^{\star \star \star} P<0.001$; ${ }^{\star \star \star \star} P<0.0001$. Box and whiskers $\mathbf{( A )}$ and error bars $\mathbf{( B )}$ show median \pm interquartile range. 
expressed $\mathrm{T}_{\mathrm{EM}}$ cells $\left(\mathrm{CD} 8{ }^{+} \mathrm{CD} 45 \mathrm{RO}^{+} \mathrm{CD} 62 \mathrm{~L}^{-}\right)$before treatment. During treatment, the median percentage of $\mathrm{CD}^{+} \mathrm{T}$-cells expressing $\mathrm{T}_{\mathrm{EM}}$ cells was notably decreased to $7.5 \%$, which was significantly low compared to before treatment $(P \leq 0.005$; $\Delta \mathrm{HL}=6.61 \%)$. However, unlike $\mathrm{CD}^{+}$and $\mathrm{CD}^{+} \mathrm{T}_{\mathrm{EM}}$ cells, the proportion of $\mathrm{CD}^{+} \mathrm{T}_{\mathrm{EM}}$ cells did not show significant change after treatment (6.5\%) (Figure 4B).

\section{$\mathbf{T}_{\mathrm{CM}}$ Cells Play Less Role in ENL Reaction}

The median percentages of $\mathrm{CD}^{+} \mathrm{T}_{\mathrm{CM}}\left(\mathrm{CD}^{+}{ }^{+} \mathrm{CD} 62 \mathrm{~L}^{+} \mathrm{CD} 45 \mathrm{RO}^{+}\right)$ cells in patients with ENL and LL controls before, during, and after treatment were not statistically significantly different $(P>0.05)$. Unlike $\mathrm{CD}^{+} \mathrm{T}_{\mathrm{CM}}$, the proportion of $\mathrm{CD}^{+} \mathrm{T}_{\mathrm{CM}}$ $\left(\mathrm{CD} 4{ }^{+} \mathrm{CD} 62 \mathrm{~L}^{+} \mathrm{CD} 45 \mathrm{RO}^{+}\right)$was significantly higher in patients with ENL (23.5\%) than in LL patient controls (14.6\%) before treatment $(P \leq 0.005 ; \Delta \mathrm{HL}=8.13 \%)$. However, the median percentage of $\mathrm{CD}^{+} \mathrm{T}_{\mathrm{CM}}$ cell was not significantly different between the two groups after treatment. Interestingly, the median percentage of $\mathrm{CD}^{+} \mathrm{T}_{\mathrm{CM}}\left(\mathrm{CD} 8{ }^{+} \mathrm{CD} 62 \mathrm{~L}^{+} \mathrm{CD} 45 \mathrm{RO}^{+}\right)$cell was significantly lower in patients with ENL (1.2\%) than in LL patient controls (3.5\%) before treatment $(P \leq 0.0001 ; \Delta \mathrm{HL}=2.3 \%)$. After treatment, the percentage of $\mathrm{CD}^{+} \mathrm{T}_{\mathrm{CM}}$ cell was slightly higher in patients with ENL (2.7\%) than in LL patient controls (2.0\%); however, the difference was not statistically significant $(P>0.05)$ (Figure 5A).

Comparison within ENL has shown that the percentage of $\mathrm{T}_{\mathrm{CM}}$ cells was not statistically significantly different before and after treatment (Figure 5B). This confirms that $\mathrm{T}_{\mathrm{CM}}$ cells do not play significant role in ENL reaction unlike $\mathrm{T}_{\mathrm{EM}}$ cells.
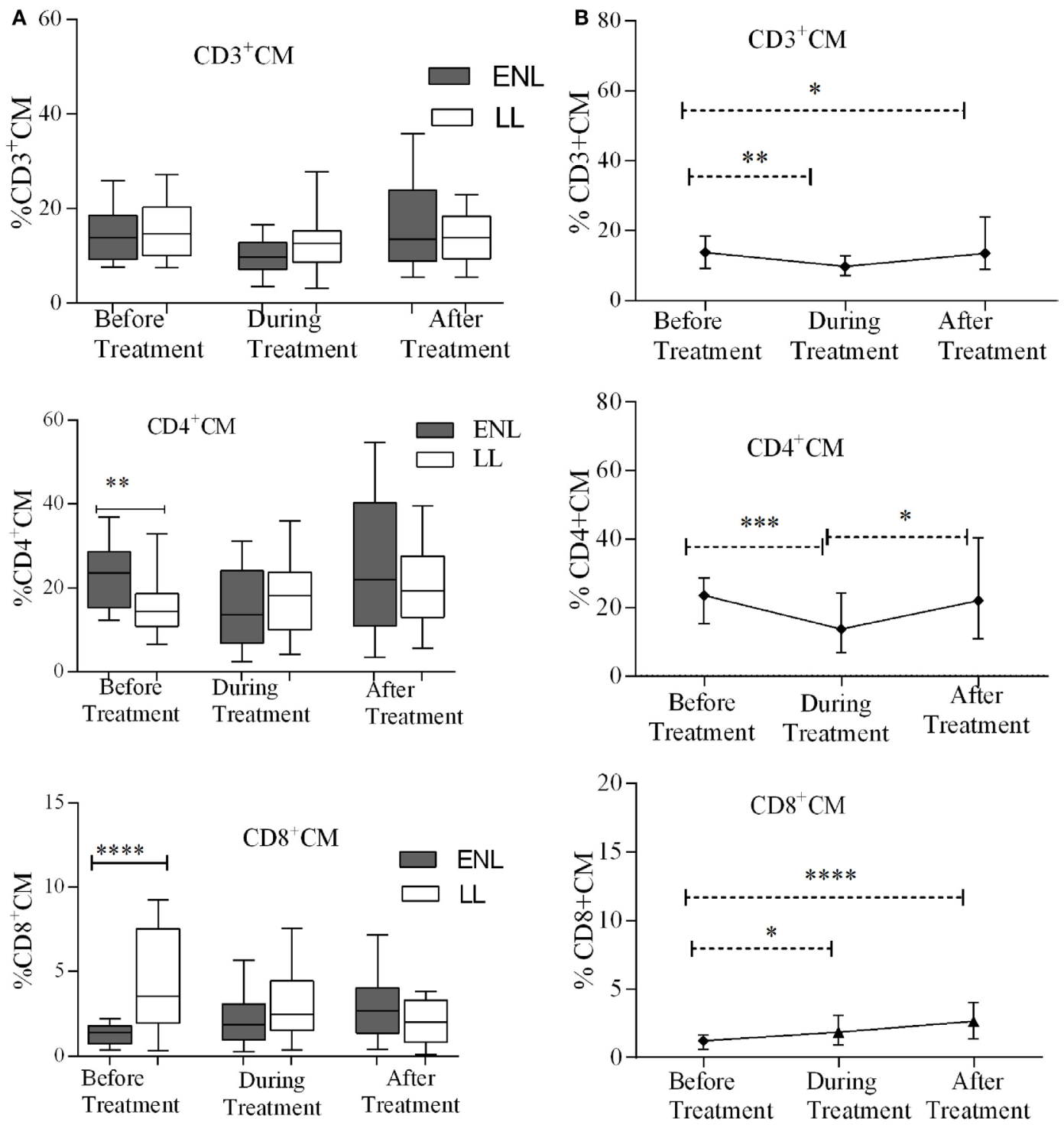

FIGURE 5 | Median percentage of $\mathrm{CD}^{+}, \mathrm{CD}^{+}$, and CD8 ${ }^{+}$central memory T-cells: (A) in patients with erythema nodosum leprosum (ENL) and lepromatous leprosy (LL) controls before, during, and after treatment, (B) within ENL patients before, during, and after treatment. ${ }^{\star} P \leq 0.05$; ${ }^{\star \star} P<0.005$; ${ }^{\star \star \star} P<0.001$; ${ }^{\star \star \star \star} P<0.0001$. Box and whiskers $(A)$ and error bars $(B)$ show median \pm interquartile range. 


\section{Increased $\mathrm{T}_{\mathrm{EC}}$ Cells in Untreated ENL Patients}

Effector memory $\mathrm{T}$-cells $\left(\mathrm{T}_{\mathrm{EC}}\right)$ are short-lived unlike memory T-cells and they shortly undergo apoptosis once they meet their cognate antigens. Nearly one-third (29.3\%) of CD3 ${ }^{+} \mathrm{T}$-cells were effector cells $\left(\mathrm{T}_{\mathrm{EC}}\right)$ in the PBMCs of patients with ENL with the corresponding value of $20.0 \%$ in LL patient controls before treatment and the difference was statistically significant $(P \leq 0.001$; $\Delta \mathrm{HL}=9.0 \%)$. After treatment, the median percentage of $\mathrm{CD}^{+}$ $\mathrm{T}_{\mathrm{EC}}$ cell was significantly decreased in patients with ENL (24.6\%) compared to LL patient controls (35.3\%) $(P \leq 0.05 ; \Delta \mathrm{HL}=8.6 \%)$. With regard to the median percentage of $\mathrm{CD} 4^{+} \mathrm{T}_{\mathrm{EC}}$ cell, a statistically significant difference was not obtained between the two groups before, during, or after treatment. The median percentage of $\mathrm{T}_{\mathrm{EC}}$ cell expression in $\mathrm{CD} 8^{+} \mathrm{T}$-cells in patients with $\mathrm{ENL}$ was $62.7 \%$, which was considerably higher than the value obtained for LL patient controls (39.5\%) before treatment $(P<0.0001$; $\Delta \mathrm{HL}=25.8 \%)$. Similar to $\mathrm{CD}^{+} \mathrm{T}_{\mathrm{EC}}$ cell, the proportion of $\mathrm{CD}^{+} \mathrm{T}_{\mathrm{EC}}$ cell in patients with ENL was significantly decreased (38.9\%) compared to LL patient controls (55.2\%) after treatment $(P \leq 0.005 ; \Delta \mathrm{HL}=14.4)$ (Figure 6A).

The median percentage of $\mathrm{CD}^{+} \mathrm{T}_{\mathrm{EC}}$ cells was lower before treatment $(29.3 \%)$ than during treatment $(43.4 \%)(P \leq 0.005)$. After treatment, the percentage of these cells decreased to $24.6 \%$. Similarly, the median percentage of $\mathrm{CD}^{+}{ }^{+} \mathrm{T}_{\mathrm{EC}}$ cells was lower before treatment (14.0\%) than during treatment $(22.9 \%)$ $(P \leq 0.05)$. After treatment, the percentage of $\mathrm{CD} 4^{+} \mathrm{T}_{\mathrm{EC}}$ cells was decreased by half $(12.1 \%)$ than during treatment $(P \leq 0.05)$. Like
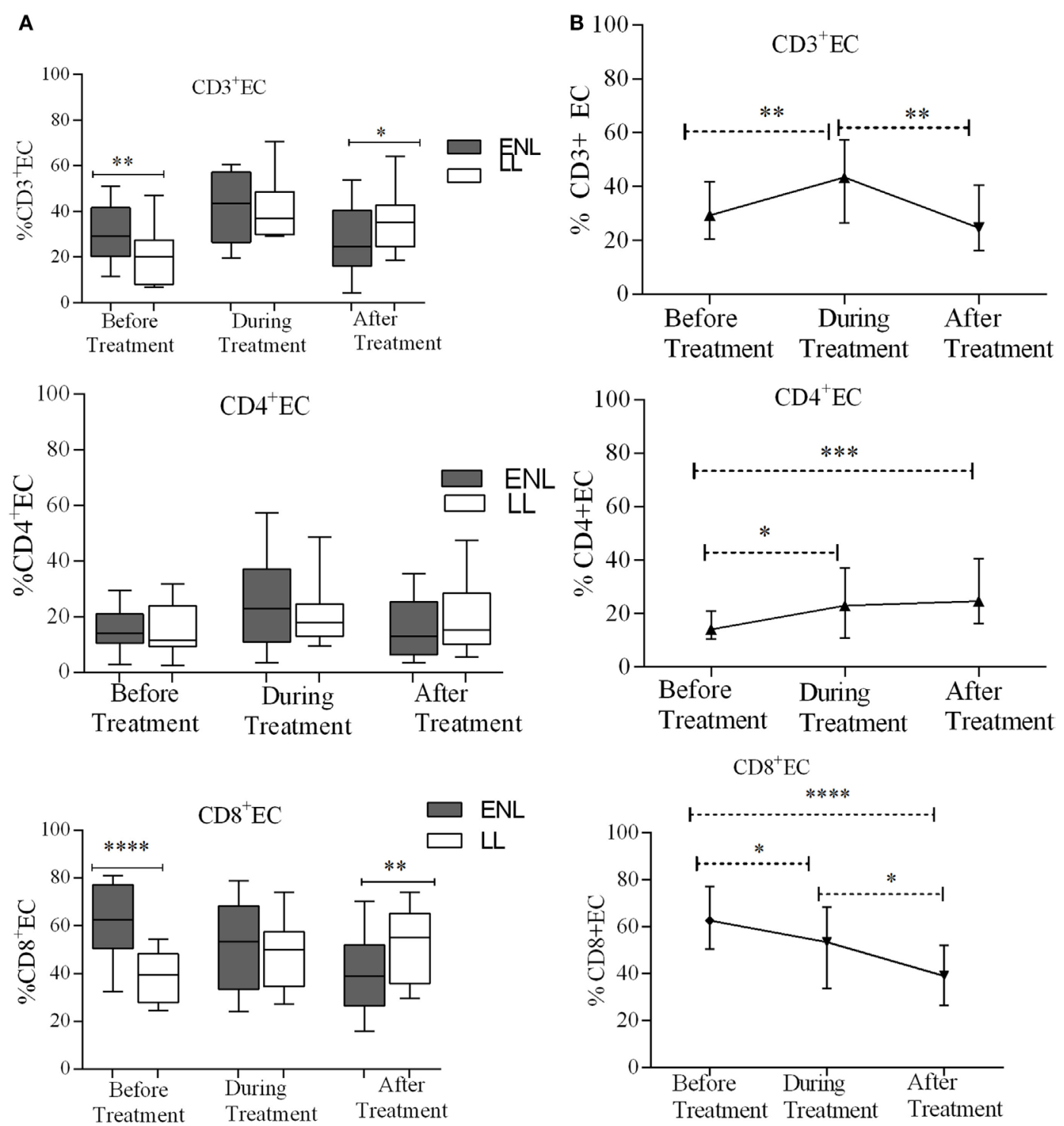

FIGURE 6 | Median percentage of $\mathrm{CD}^{+}, \mathrm{CD}^{+}$, and CD8+ effector T-cells: (A) in patients with erythema nodosum leprosum (ENL) and lepromatous leprosy (LL) controls before, during, and after treatment, (B) within ENL patients before, during, and after treatment. ${ }^{\star} P \leq 0.05 ;{ }^{\star \star \star} P<0.005 ;{ }^{\star \star \star} P<0.001 ;{ }^{\star \star \star \star} P<0.0001$. Box and whiskers $\mathbf{( A )}$ and error bars $\mathbf{( B )}$ show median \pm interquartile range. 
$\mathrm{CD}^{+} \mathrm{T}_{\mathrm{EC}}$ cells, the percentage of $\mathrm{CD} 4^{+} \mathrm{T}_{\mathrm{EC}}$ cells did not show significant difference before and after treatment. On the other hand, the median percentage of $\mathrm{CD}^{+} \mathrm{T}_{\mathrm{EC}}$ cells was higher $(62.7 \%)$ before treatment than during treatment $(53.4 \%)(P \leq 0.05)$. After treatment, the percentage of $\mathrm{CD}^{+} \mathrm{T}_{\mathrm{EC}}$ cells was considerably decreased to $38.9 \%$ compared to during treatment $(P \leq 0.05)$ and before treatment $(P<0.0001)$ (Figure 6B).

\section{$\mathrm{N}_{\mathrm{TC}}$ S Decreased in ENL Patients Compared to Non-Reactional LL Controls}

Despite the higher bacterial load in patients with LL patients, the median percentage of $\mathrm{CD}^{+} \mathrm{N}_{\mathrm{TC}} \mathrm{S}$ was significantly higher (59.5\%) in these patients compared to that in patients with ENL (27.7\%) before treatment $(P<0.0001 ; \Delta \mathrm{HL}=26.5 \%)$. During treatment, the median percentage of $\mathrm{CD}^{+} \mathrm{N}_{\mathrm{TC}} \mathrm{S}$ significantly decreased to $32.9 \%$ in LL patient controls while in patients with ENL the percentage was slightly increased to $31.8 \%$. After treatment, the percentage of $\mathrm{CD}^{+} \mathrm{N}_{\mathrm{TC}} \mathrm{S}$ was further increased to $42.9 \%$ in patients with ENL but did not change in LL patient controls (33.0\%), and the difference between the two groups was statistically significant. Similarly, the median percentage of $\mathrm{CD}^{+}$ $\mathrm{N}_{\mathrm{TC}} \mathrm{S}$ in patients with ENL (34.0\%) was significantly lower than that in LL patient controls $(61.5 \%)$ before treatment $(P<0.0001$; $\Delta \mathrm{HL}=25.6 \%)$. However, during and after treatment the median percentage of $\mathrm{CD}^{+} \mathrm{N}_{\mathrm{TC}}$ did not show statistically significant difference $(P>0.05)$. On the other hand, the median percentage of $\mathrm{CD}^{+} \mathrm{N}_{\mathrm{TC}} \mathrm{S}$ in patients with ENL was more than three times lower $(15.4 \%)$ than in LL patient controls $(50.5 \%)$ before treatment $(P<0.0001 ; \Delta \mathrm{HL}=31.6 \%)$. During treatment, while the median percentage of $\mathrm{CD}^{+} \mathrm{N}_{\mathrm{TC}} \mathrm{S}$ increased to $35.5 \%$ in patients with ENL, it was decreased to $38 \%$ in LL patient controls. After treatment, the median percentage of $\mathrm{CD}^{+} \mathrm{N}_{\mathrm{TC}}$ in patients with ENL and LL controls was 51.5 and $32.8 \%$, respectively, and the difference between the two groups was statistically significant $(P \leq 0.05 ; \Delta \mathrm{HL}=14.4 \%)($ Figure 7A).

Comparison within ENL has shown that the percentage of $\mathrm{CD}^{+} \mathrm{T}_{\mathrm{NC}}$ cell was lower $(27.7 \%)$ before than after treatment (42.9\%) $(P<0.0001)$. Similarly, the percentage of $\mathrm{CD}^{+} \mathrm{T}_{\mathrm{NC}}$ cells was lower $(34.1 \%)$ before treatment than after treatment (40.4\%) $(P \leq 0.005)$. The percentage of $\mathrm{CD}^{+} \mathrm{T}_{\mathrm{NC}}$ cells was $15.4 \%$ before treatment but increased to $51.5 \%$ after treatment and it was significantly higher than before treatment $(P<0.0001)$ (Figure 7B).

\section{Decreased Regulatory T-Cells $\left(T_{\text {reg }}\right) / T_{\mathrm{EM}}$ Cells Ratio in ENL Patients Compared to LL Controls}

The median percentage ratio of $\mathrm{T}_{\text {reg }}\left(\mathrm{CD} 3^{+} \mathrm{CD} 4^{+} \mathrm{CD} 25^{+} \mathrm{FoxP}^{+}\right)$ to $\mathrm{T}_{\mathrm{EM}}\left(\mathrm{T}_{\mathrm{reg}} / \mathrm{T}_{\mathrm{EM}}\right.$ cells $)$ was significantly lower in untreated patients with ENL (0.077) than in LL controls (0.44) before treatment $(P \leq 0.0001)$. However, after treatment the median percentage ratio of $\mathrm{T}_{\text {reg }} / \mathrm{T}_{\mathrm{EM}}$ cells was significantly increased in patients with ENL (0.522) compared LL controls $(0.255)(P \leq 0.005)$ (Figure 8A).

When the ratio of $\mathrm{T}_{\text {reg }} / \mathrm{T}_{\mathrm{EM}}$ cells is compared within ENL groups, it was found that patients with ENL had a significantly lower median percentage of $\mathrm{T}_{\text {reg }} / \mathrm{T}_{\mathrm{EM}}$ cells $(0.077)$ before treatment than after treatment $(0.552)(P<0.0001)$ (Figure 8B).

\section{DISCUSSION}

The ability of inflammatory cells to respond to pathogens is crucial for maintaining healthy conditions. In mammals, lymphocytes leave the circulation and migrate to secondary lymphoid organs, such as lymph nodes, where antigens are presented. When an antigen is encountered, directed release of immune cells to sites of inflammation orchestrates host defense. Both constitutive and inflammatory leukocyte trafficking is controlled by adhesion molecules. The initial tethering of leukocytes to the endothelium and to other leukocytes is assisted by selectins, particularly by L-selectins. L-selectin directs neutrophils and lymphocytes to sites of inflammation. Upon T-cell activation L-selectin is shed from the leukocyte surface $(8,20)$.

In this study, the status of T-cell activation and the different subtypes of memory T-cells were investigated. In leprosy, the different classes of memory T-cells have not been studied. To our knowledge, it is for the first time that the different subtypes of memory T-cells and T-cell activation are phenotypically described in patients with ENL and LL. We are the first to study the status of T-cell activation in patients with ENL. Not only $\mathrm{T}$-cell activation and the different classes of memory T-cells are described but also the changes of these immune cells over time before, during, and after prednisolone treatment were investigated. Therefore, our present data will provide basic information for future studies involving T-cell activation and memory T-cells in ENL.

\section{Increased Activation of T-Cells in Entreated ENL}

In our study, patients with ENL had significantly higher percentage of $\mathrm{CD}^{+}, \mathrm{CD}^{+}$, and $\mathrm{CD}^{+}$activated T-cells than LL patient controls before treatment. However, after prednisolone treatment, T-cell activation was not significantly different in patients with ENL and LL controls except for the transient activation of $\mathrm{CD}^{+} \mathrm{T}$-cells. This result is the evidence of T-cell activation in patients with ENL reactions. In vitro stimulation of PBMCs from patients with ENL reaction with $M$. leprae whole-cell sonicate has shown an increased T-cell response as assessed by IFN- $\gamma$ and TNF- $\alpha$ production (data not shown). Excessive T-cell activation as a cause of tissue damage in several inflammatory diseases has been described in many studies $(21,22)$. The finding of T-cell activation in patients with ENL implies the involvement of T-cell activation in the pathogenesis of ENL.

In this study, changes in the percentage of activated T-cells were investigated before, during, and after prednisolone treatment within ENL groups. The percentages of $\mathrm{CD}^{+}, \mathrm{CD}^{+}$, and $\mathrm{CD}^{+}$activated T-cells were significantly reduced during and after prednisolone treatment. The reduction of activated T-cells following prednisolone treatment may be explained by the immunosuppressive activity of prednisolone. Although studies showing the effect of prednisolone treatment on T-cell response in leprosy reactions is lacking, several studies in other 


\section{A}

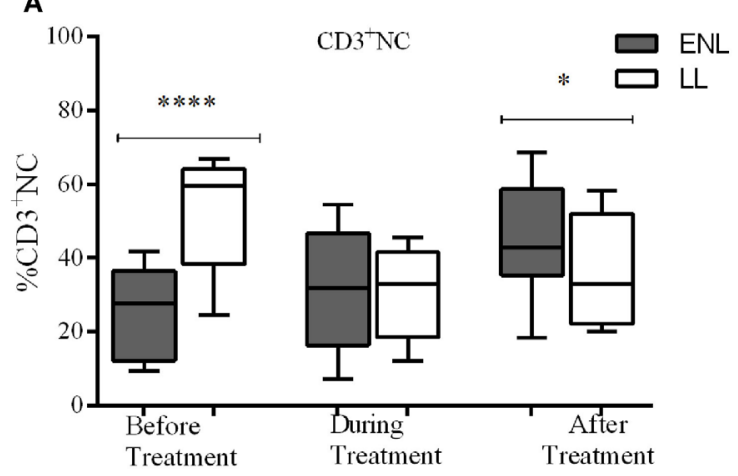

$\mathrm{CD}^{+} \mathrm{NC}$
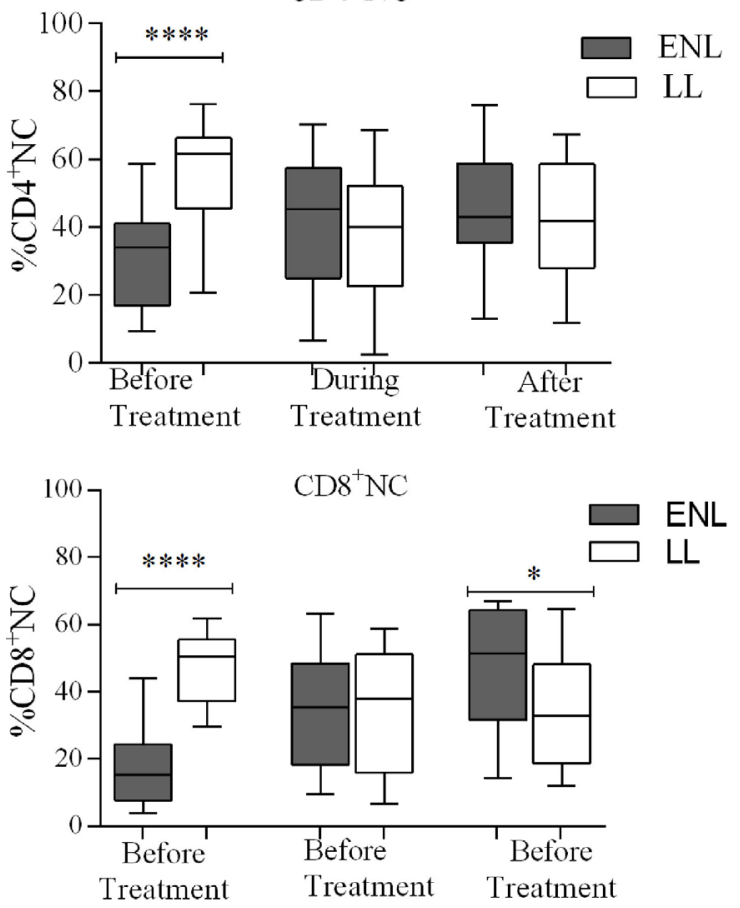

ENL

LL
B

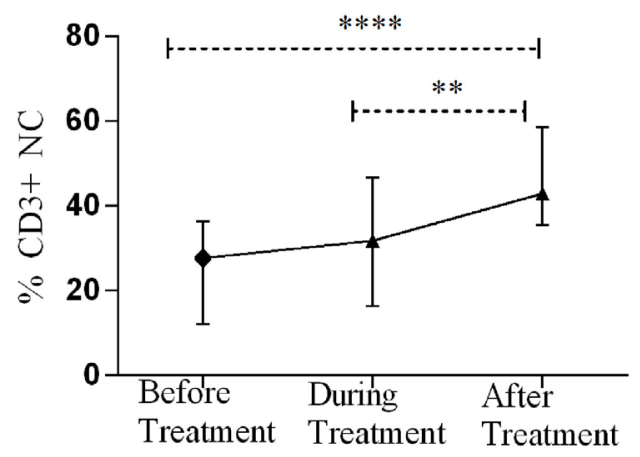

$\mathrm{CD} 4^{+} \mathrm{NC}$

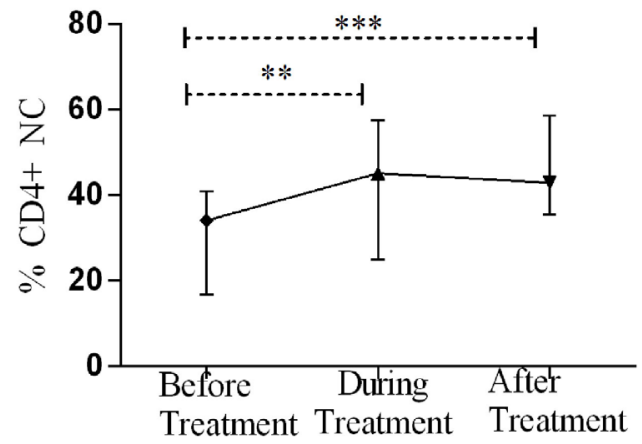

$\mathrm{CD}^{+} \mathrm{NC}$

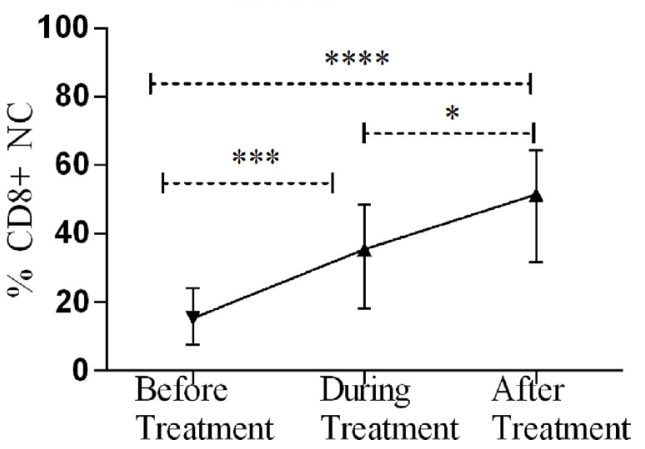

FIGURE 7 | Median percentage of $\mathrm{CD}^{+}, \mathrm{CD}^{+}$, and CD8 ${ }^{+}$naïve T-cells: (A) in patients with erythema nodosum leprosum (ENL) and lepromatous leprosy (LL) controls before, during, and after treatment, (B) within ENL patients before, during, and after treatment. ${ }^{\star} P \leq 0.05 ;{ }^{\star \star} P<0.005 ;{ }^{\star \star \star} P<0.001$; ${ }^{\star \star \star \star} P<0.0001$. Box and whiskers $\mathbf{( A )}$ and error bars $\mathbf{( B )}$ show median \pm interquartile range.

inflammatory diseases have shown the suppressive effect of prednisolone on the T-cell response (23-25). Consequently, our present findings provide evidence that the effect of prednisolone treatment of patients with ENL could be through suppressing T-cell responses.

\section{$T_{E M}$ Cells Significantly Increased in Untreated ENL Patients}

The median percentage of $\mathrm{CD}^{+}, \mathrm{CD}^{+}$, and $\mathrm{CD}^{+}$T-cells expressing $\mathrm{T}_{\mathrm{EM}}$ cells in the PBMCs of patients with ENL was significantly high compared to LL patient controls before treatment. Such a difference was not observed after prednisolone treatment of patients with ENL. This implies that in patients with ENL, there is a continuous activation of T-cells. This continuous T-cell activation could lead to an excess antibody-antigen complex formation but insufficient to clear bacilli from lesions (26). This means the rate of immune-complex formation is greater than the rate of immune-complex clearance, which leads to further tissue damage through recruitment of inflammatory molecules to the site of immune-complex deposition. In LL, there is high load of bacilli. The macrophages are laden with this intact bacillus but unable to process and present to T-cells for further action. LL patients are also characterized by the presence of high antibody titer although these antibodies play little or no role to protect the multiplication of $M$. leprae in these patients. Spontaneous 

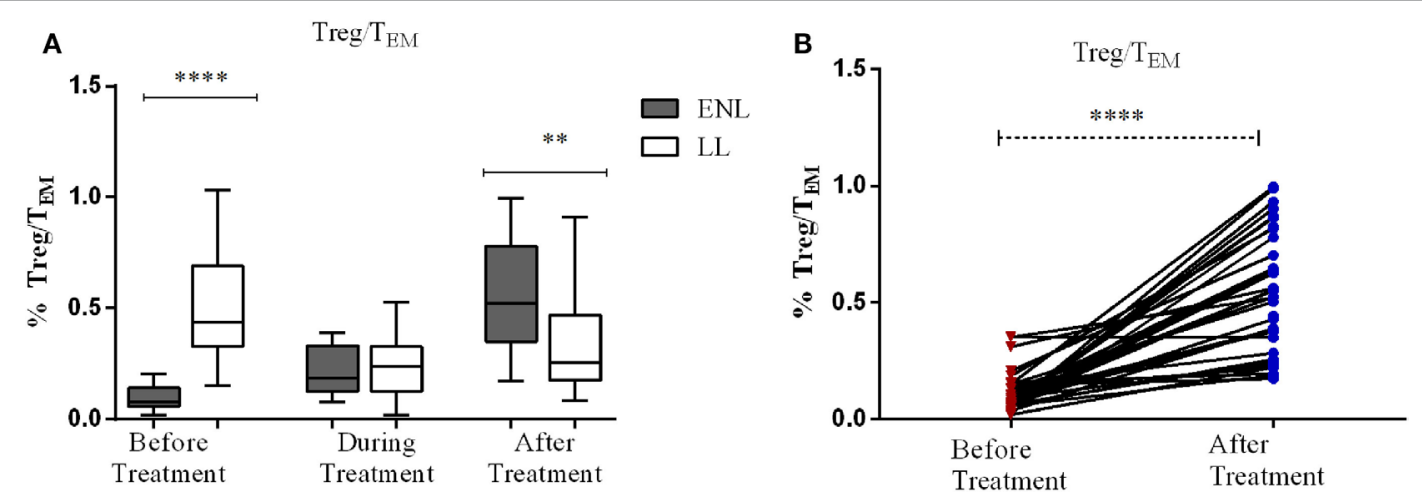

FIGURE 8 | The median percentage of regulatory T-cells $\left(T_{\text {reg }}\right)$ /effector memory T-cells (TEM) cells: (A) in patients with erythema nodosum leprosum (ENL) and lepromatous leprosy (LL) controls before, during, and after treatment, (B) within ENL patients before, during, and after treatment. ${ }^{\star \star} P<0.005$; ${ }^{\star \star \star} P<0.001$; ${ }^{\star * \star *} P<0.0001$.

activation of T-cells could lead to the macrophage activation or B-cell activation or both. Macrophage activation results in the processing of the bacilli and releasing the processed bacterial components, which further activate other immune cells. The activation of B-cells by T-cells could produce functional antibodies, which form immune-complex with the already accumulated bacterial antigens. However, this scenario is less likely to happen as it is confirmed that the different subtypes of B-cells did not significantly different in ENL and LL patients (data not shown). Whichever the activation takes place, if excess immune-complex is formed due to the presence of excess antigens in the body, it leads to more immune-complex formation than immunecomplex clearance, and hence, some immune-complexes deposit in tissues and often induce inflammatory responses and can cause tissue damage. The causes of tissue damage could be due to the action of complement cleavages, which induces the release of tissue damaging granules such as histamine or the recruitment of inflammatory cells such as neutrophils and macrophages into the tissue. However, this assumption needs further study to give definitive evidence. Previous studies have suggested that human $T_{E M}$ cells display characteristic sets of chemokine receptors and adhesion molecules that are required for homing to inflamed tissues and they have an immediate effector function $(20,27)$. This situation could amplify the immune response and hence further aggravate tissue damage in a vicious circle (Figure 9).

A kinetic analysis of the percentage of $\mathrm{T}_{\mathrm{EM}}$ cells in the PBMCs from patients with ENL before, during, and after prednisolone treatment showed that the median percentage of $\mathrm{T}_{\mathrm{EM}}$ cells was decreased from $27 \%$ before treatment to $8 \%$ after treatment with an effect size of $20 \%$. It has been described in previous sections that $\mathrm{T}_{\mathrm{EM}}$ cells rapidly differentiate to $\mathrm{T}_{\mathrm{EC}}$ cells upon antigenic stimulation. The consequence of excessive expression of $\mathrm{T}_{\mathrm{EM}}$ cells is detrimental to tissue damage (9). In apparently healthy individuals, $\mathrm{T}_{\mathrm{EC}}$ cells do not express CD62L or CCR7 and hence do not home to lymph nodes (10). A breakdown in the compartmentalization of such $\mathrm{T}_{\mathrm{EC}}$ cells is predicted to have unfavorable consequences for the immune system. Hence, the finding of an increased percentage of $T_{E M}$ cells in patients with ENL before treatment suggests that $\mathrm{T}_{\mathrm{EC}}$ cells take part in the process of tissue damage observed in these patients.

\section{More T-Cells in ENL Patients Are Antigen Experienced than in LL Patients}

Interestingly, the median percentage of $\mathrm{N}_{\mathrm{TC}}$ ' expression in $\mathrm{CD}^{+}$, $\mathrm{CD}^{+}$, and $\mathrm{CD} 8^{+} \mathrm{T}$-cells in the PBMCs of patients with ENL was significantly low compared to LL controls before treatment implying that T-cells from patients with ENL have more antigenic exposure than those from LL. It is important to note that patients with ENL had LL before they developed ENL during which a high percentage of $\mathrm{N}_{\mathrm{TC}} \mathrm{S}$ is expected since higher percentage of $\mathrm{N}_{\mathrm{TC}} \mathrm{S}$ was investigated in this study in LL patients. Following the development of ENL, the percentage of $\mathrm{N}_{\mathrm{TC}}$ drops to below $30 \%$. This implies that either those previously $\mathrm{N}_{\mathrm{TC}}$ became responsive and able to recognize their cognate antigen or the newly produced T-lymphocytes during the onset of ENL reactions are able to recognize and respond to the existing $M$. leprae antigens unlike in LL. It is an established fact that despite the high bacterial load in patients with LL, the cell-mediated immune response is virtually absent $(28,29)$. In addition to a specific loss of cell-mediated immune response against $M$. leprae in these patients, a relative impairment of the ability of lymphocytes to react in vitro has also been reported. Furthermore, lymph nodes from patients with LL show a deficiency of these cells in those areas associated with the development of cell-mediated immune responses (14, 28-31). Therefore, the significantly reduced median percentage of $\mathrm{N}_{\mathrm{TCS}}$ in blood from patients with ENL reaction provides an evidence of T-cell responsiveness in patients with ENL. This means that unlike in LL patients, the $\mathrm{N}_{\mathrm{TC}}$ in ENL patients are primed in recognition of the $M$. leprae antigen (Figure 9).

The median percentage of $\mathrm{N}_{\mathrm{TC}} \mathrm{S}$ was significantly increased after prednisolone treatment within ENL groups. The percentage of $\mathrm{N}_{\mathrm{TC}}$ in untreated patients with ENL reactions was less than $30 \%$ and was increased to nearly $50 \%$ after treatment. Previous studies have shown that prednisolone treatment increases in a dose-dependent manner the percentage of $\mathrm{N}_{\mathrm{TC}}$ in experimental 


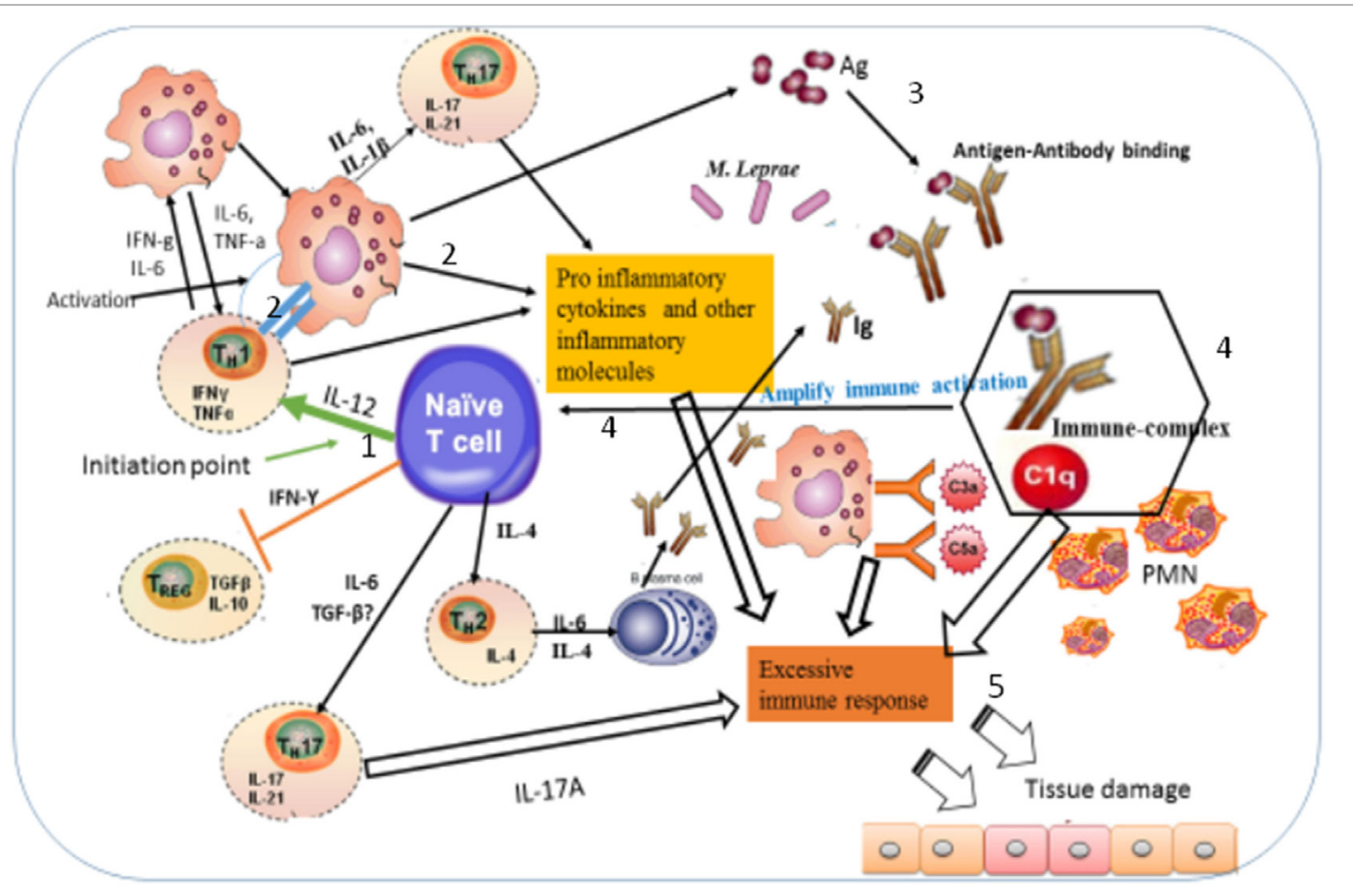

FIGURE 9 | Illustration of the possible immunopathogenesis of erythema nodosum leprosum (ENL) based on the present findings. Based on the finding of this study, the immunopathogenesis of ENL can be illustrated using the following key steps: (1) spontaneous activation of T-cells leading to activation of macrophages that are already loaded with intact Mycobacterium leprae. Then, the activation of macrophages produces three key events: processing $M$. leprae and releasing of the processed antigens; antigen presentation to Th1 and production of pro-inflammatory cytokines such as IFN- $\gamma$ and TNF- $\alpha$ and other inflammatory molecules. The causes of spontaneous T-cell activation should be investigated in the future. (2) Antigen presentation to Th1 stimulates Th1 to produce chemokines, which recruits macrophages to the site of antigen deposition, pro-inflammatory cytokines (IFN- $\gamma$, TNF- $\alpha$ ), and other inflammatory mediators that increase expression of vascular adhesion molecules. (3) The processed and released antigens bind to the presynthesized antibody leading to antigen-antibody complex formation, which in turn recruits $\mathrm{C} 1 \mathrm{q}$ complement and hence immune-complex formation. Following the immune-complex formation, neutrophils will be recruited to the site of immunecomplexes. (4) Once immune-complex is formed, it amplifies the immune response which leads to aggressive antigen presentation, immunoglobulin synthesis, and activation of other inflammatory T-cells. (5) The pro-inflammatory cytokines and other inflammatory molecules released from macrophages, Th17, and Th1 and the immune-complex formation beyond clearance lead to tissue damage as sketched above.

mice. Hence, the finding of high percentages of $\mathrm{N}_{\mathrm{TC}} \mathrm{S}$ after prednisolone treatment of patients with ENL may be explained by the fact that prednisolone resolves inflammation at least partly by increasing the percentage of $\mathrm{N}_{\mathrm{TC}} \mathrm{S}$ which concurrently reduce the percentage of activated T-cells.

In our present work, we have shown that ENL reaction is associated with increased T-cell activation. Our findings suggest that ENL reaction is a T-cell-mediated pathology. Hence, the T-cell-mediated pathology of ENL will provide further insights into disease mechanisms and will potentially result in promising new therapeutic options. Therefore, future ENL studies should consider these fertile areas to improve the treatment and management of ENL. It might also be important to think of to interfere with T-cell trafficking into tissues and thereby reducing inflammation in these patients.

\section{ETHICS STATEMENT}

Informed written consent for blood samples was obtained from patients following approval of the study by the Institutional Ethical Committee of London School of Hygiene and Tropical Medicine,
UK (\#6391), AHRI/ALERT, Ethiopia (P032/12), and the National Research Ethics Review Committee, Ethiopia (\#310/450/06). All data have been analyzed and reported anonymously.

\section{AUTHOR CONTRIBUTIONS}

EN and DL formulated the study questions. EN, DL, HD, SW, and $\mathrm{KB}$ designed the study protocol. EN, BE, and $\mathrm{KB}$ conducted the experiment. AA, HD, and DL supervised the study. EN analyzed the data. All the authors contributed to the interpretation of the data. EN drafted the manuscript. KB, SW, BE, RH, AA, HD, and $\mathrm{DL}$ revised the manuscript. All the authors read and approved the final version for publication. All the authors agreed to be accountable for all aspects of the work in ensuring that questions related to the accuracy or integrity of any part of the work are appropriately investigated and resolved.

\section{ACKNOWLEDGMENTS}

We would like to thank the participants who volunteered to donate blood sample and sacrificed their time to participate 
in this study. We would like to thank in particular, the study nurses Sr. Genet Amare and Sr. Haregewoin, study coordinator Mr. Fikre Mekuria, our tracer, Mr. Yilma Tesfaye, the Red Medical Clinic nurses, and Dr. Yonas Bekele for his help in the lab work. We would like to extend our sincere gratitude to Suzan Sheedy whose administrative support at LSHTM has been invaluable and AHRI staff for their unreserved support. Mr. Dawit Bogale should receive our sincere thanks for his

\section{REFERENCES}

1. Ridley MJ, Ridley DS. The immunopathology of erythema nodosum leprosum: the role of extravascular complexes. Lepr Rev (1983) 54(2):95-107.

2. Lockwood DN, Vinayakumar S, Stanley JN, McAdam KP, Colston MJ. Clinical features and outcome of reversal (type 1) reactions in Hyderabad, India. Int J Lepr Other Mycobact Dis (1993) 61(1):8-15.

3. Walker SL, Lebas E, Doni SN, Lockwood DNJ, Lambert SM. The mortality associated with erythema nodosum leprosum in Ethiopia: a retrospective hospital-based study. PLoS Negl Trop Dis (2014) 8(3):e2690. doi:10.1371/ journal.pntd.0002690

4. Pocaterra L, Jains S, Reddy R, Muzaffarullah S, Torres S, Suneetha S, et al. Clinical course of erythema nodosum leprosum: an 11-year chohort study in Hyderabad, India. Am J Trop Med Hyg (2006) 74(5):868-79. doi:10.4269/ ajtmh.2006.74.868

5. Mueller SN, Gebhardt T, Carbone FR, Heath WR. Memory T cell subsets, migration patterns, and tissue residence. Annu Rev Immunol (2013) 31:37-61. doi:10.1146/annurev-immunol-032712-095954

6. Vita G, Lijun W. Different subsets of T cells, memory, effector functions, and CAR-T immunotherapy. Cancers (2016) 8(36):1-12. doi:10.3390/ cancers8030036

7. Mackenziea KJ, Nowakowskaa DJ, Leecha MD, McFarlanea AJ, Wilsonc C, Fitcha PM, et al. Effector and central memory T helper 2 cells respond differently to peptide immunotherapy. Proc Natl Acad Sci US A (2014) 111:E784-93. doi:10.1073/pnas.1316178111

8. Raffler NA, Rivera-Nieves J, Ley K. L-selectin in inflammation, infection and immunity. Drug Discov Today (2005) 2(3):213-20. doi:10.1016/j.ddstr. 2005.08.012

9. Farber DL, Yudanin NA, Restifo NP. Human memory T cells: generation, compartmentalization and homeostasis. Nat Rev Immunol (2014) 14(1):24-35. doi:10.1038/nri3567

10. Flynn JK, Gorry PR. Stem memory T cells (TSCM)[mdash]their role in cancer and HIV immunotherapies. Clin Trans Immunol (2014) 3:e20. doi:10.1038/cti.2014.16

11. Mitra DK, De Rosa SC, Luke A, Balamurugan A, Khaitan BK, Tung J, et al. Differential representations of memory $\mathrm{T}$ cell subsets are characteristic of polarized immunity in leprosy and atopic diseases. Int Immunol (1999) 11(11):1801-10. doi:10.1093/intimm/11.11.1801

12. Esquenazi D, Alvim IMP, Pinheiro RO, Oliveira EB, Moreira LO, Sarno EN, et al. Correlation between central memory $\mathrm{T}$ cell expression and proinflammatory cytokine production with clinical presentation of multibacillary leprosy relapse. PLoS One (2015) 10(5):e0127416. doi:10.1371/journal.pone.0127416

13. dos Santos L, da Silva P, Alvim I, Nery J, Lara F, Sarno E, et al. Role of TEFFECTOR/MEMORY Cells, TBX21 gene expression and T-cell homing receptor on type 1 reaction in borderline lepromatous leprosy patients. PLoS One (2016) 11(10):e0164543. doi:10.1371/journal.pone.0164543

14. Bobosha K, Wilson L, van Meijgaarden KE, Bekele Y, Zewdie M, van der Ploeg-van Schip JJ, et al. T-cell regulation in lepromatous leprosy. PLoS Negl Trop Dis (2014) 8(4):e2773. doi:10.1371/journal.pntd.0002773

15. Thompson ML, Kunkel EJ, Ehrhardt RO. Cryopreservation and Thawing of Mammalian Cells. New York: John Wiley \& Sons, Ltd (2001).

16. Mohan VP, Scanga CA, Yu K, Scott HM, Tanaka KE, Tsang E, et al. Effects of tumor necrosis factor alpha on host immune response in chronic persistent tuberculosis: possible role for limiting pathology. Infect Immun (2001) 69(3):1847-55. doi:10.1128/IAI.69.3.1847-1855.2001

17. Ehlers S. Tumor necrosis factor and its blockade in granulomatous infections: differential modes of action of infliximab and etanercept? Clin Infect Dis (2005) 41(Suppl 3):S199-203. doi:10.1086/429998 fast and on time custom clearance of our reagents. Finally, we would like to acknowledge Homes and Hospital of St Gilles for funding the project and Armauer Hansen Research Institute for allowing us to use all laboratory facilities.

\section{FUNDING}

The study was funded by Homes and Hospitals of St Giles, UK.

18. Gail F. Twenty nonparametric statistics and their large sample approximations. JMod Appl Stat Methods (2002) 1(2):248-68. doi:10.22237/jmasm/ 1036110540

19. Seder RA, Darrah PA, Roederer M. T-cell quality in memory and protection: implications for vaccine design. Nat Rev Immunol (2008) 8(4):247-58. doi:10.1038/nri2274

20. Sallusto F, Geginat J, Lanzavecchia A. Central memory and effector memory T cell subsets: function, generation, and maintenance. Annu Rev Immunol (2004) 22:745-63. doi:10.1146/annurev.immunol.22.012703.104702

21. Baniyash M. TCR [zeta]-chain downregulation: curtailing an excessive inflammatory immune response. Nat Rev Immunol (2004) 4(9):675-87. doi: $10.1038 /$ nri1434

22. Park CO, Kupper TS. The emerging role of resident memory T cells in protective immunity and inflammatory disease. Nat Med (2015) 21(7):688-97. doi:10.1038/nm.3883

23. Hepburn B, Slade JD. Effect of divided daily dose prednisone therapy on circulating T cell subsets. J Rheumatol (1987) 14(1):19-22.

24. Shevach EM. Mechanisms of Foxp3+ T regulatory cell-mediated suppression. Immunity (2009) 30:636-45. doi:10.1016/j.immuni.2009.04.010

25. Kasang C, Kalluvya S, Majinge C, Kongola G, Mlewa M, Massawe I, et al. Effects of prednisolone on disease progression in antiretroviral-untreated HIV infection: a 2-year randomized, double-blind placebo-controlled clinical trial. PLoS One (2016) 11(1):e0146678. doi:10.1371/journal.pone.0146678

26. Cooper CL, Mueller C, Sinchaisri TA, Pirmez C, Chan J, Kaplan G, et al. Analysis of naturally occurring delayed-type hypersensitivity reactions in leprosy by in situ hybridization. JExp Med (1989) 169(5):1565-81. doi:10.1084/jem.169.5.1565

27. Kaech SM, Wherry EJ, Ahmed R. Effector and memory T-cell differentiation: implications for vaccine development. Nat Rev Immunol (2002) 2(4):251-62. doi: $10.1038 /$ nri778

28. Godal T, Myklestad B, Samuel DR, Myrvang B. Characterization of the cellular immune defect in lepromatous leprosy: a specific lack of circulating Mycobacterium leprae-reactive lymphocytes. Clin Exp Immunol (1971) 9(6):821-31.

29. Godal T, Myrvang B, Froland SS, Shao J, Melaku G. Evidence that the mechanism of immunological tolerance ('central failure') is operative in the lack of host resistance in lepromatous leprosy. Scand J Immunol (1972) 1(4):311-21. doi:10.1111/j.1365-3083.1972.tb03296.x

30. Myrvang B, Godal T, Ridley DS, Fröland SS, Song YK. Immune responsiveness to Mycobacterium leprae and other mycobacterial antigens throughout the clinical and histopathological spectrum of leprosy. Clin Exp Immunol (1973) 14(4):541-53.

31. Kaplan G, Weinstein DE, Steinman RM, Levis WR, Elvers U, Patarroyo ME, et al. An analysis of in vitro $\mathrm{T}$ cell responsiveness in lepromatous leprosy. J Exp Med (1985) 162(3):917-29. doi:10.1084/jem.162.3.917

Conflict of Interest Statement: The authors declare that the research was conducted in the absence of any commercial or financial relationships that could be construed as a potential conflict of interest.

Copyright (c) 2017 Negera, Bobosha, Walker, Endale, Howe, Aseffa, Dockrell and Lockwood. This is an open-access article distributed under the terms of the Creative Commons Attribution License (CC BY). The use, distribution or reproduction in other forums is permitted, provided the original author(s) or licensor are credited and that the original publication in this journal is cited, in accordance with accepted academic practice. No use, distribution or reproduction is permitted which does not comply with these terms. 